\title{
Sustaining the South East Asian wood products sector through education: the German lesson
}

\begin{abstract}
While human capital is recognized as an important productivity driver, the South East Asian wood products sector has not paid attention to the human resource development agenda comparable to the scale shown by their German counterparts. The competitive edge of the German wood products sector is attributed to the training and education of a competent workforce, which is able to capitalize on the state of the art woodworking technology. A competent and highly trained workforce is a prerequisite for the sustainable growth of the South East Asian wood products sector, as they embark on the manufacture of greater valueadded wood products.
\end{abstract}

Keyword: Competent workforce, Human capital, Training and education, Value-added wood products sector 